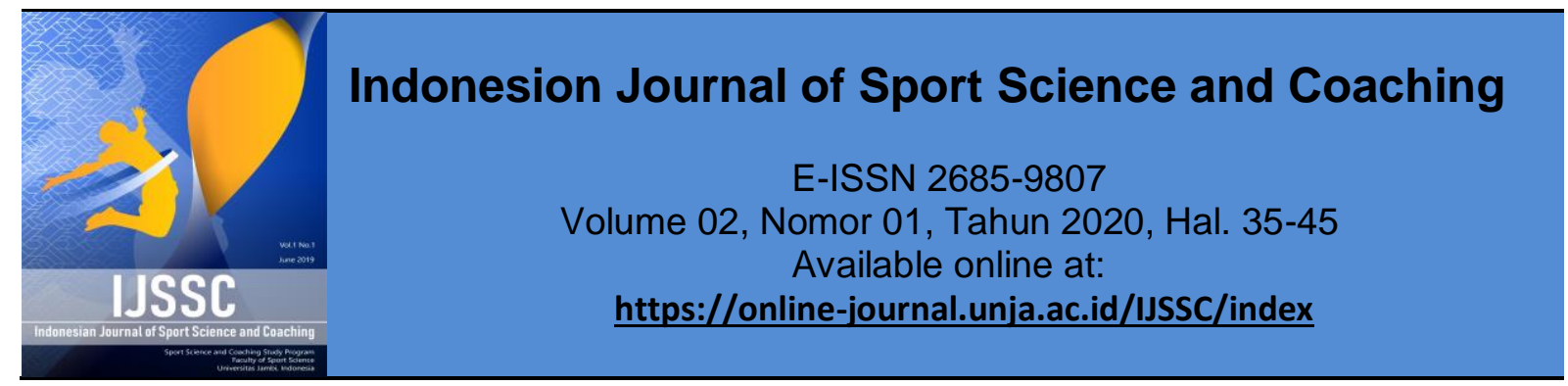

Research Article

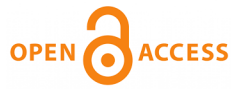

\title{
Survey Penerapan Kurikulum 2013 Pada Mata Pelajaran Penjas Di Sekolah Menengah Pertama Negeri
}

\section{(Survey on the Implementation of the 2013 Curriculum in Physical Education Subjects at Public Middle Schools)}

*GioFani Pangaribuan, Rifqi Aufan

Fakultas IImu Keolahragaan, Universitas Negeri Medan

Jalan Willem Iskandar, Pasar V Medan Estate, Kenangan Baru, Kec. Percut Sei Tuan,

Kabupaten Deli Serdang, Sumatera Utara 20221 Medan, Indonesia

*Corresponding author: giofanipangaribuan@gmail.com

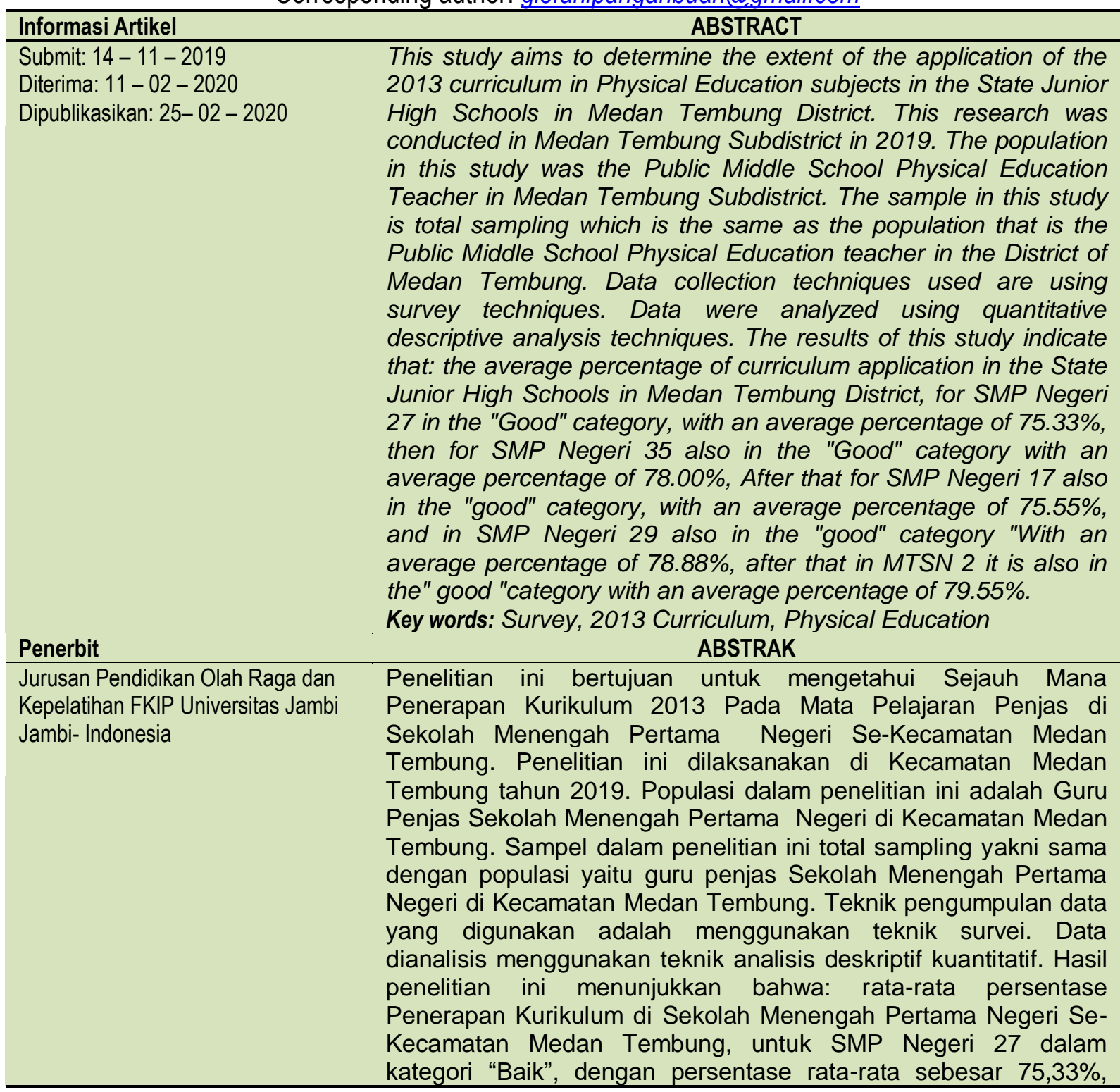


Kemudian untuk SMP Negeri 35 juga dalam kategori "Baik" dengan presentase rata-rata sebesar $78,00 \%$, Setelah itu untuk SMP Negeri 17 juga dalam kategori "baik", dengan persentase rata-rata sebesar 75,55\%, Dan di SMP Negeri 29 juga dalam kategori "baik" dengan persentase rata-rata 78,88\%, Setelah itu di MTSN 2 juga dalam kategori "baik" dengan persentasu rata-rata $79,55 \%$

Kata kunci: Survei, Kurikulum 2013, Penjas

This Indonesian Journal of Sport Science and Coaching is licensed under a CC BY-NC-SA (Creative Commons Attribution-ShareAlike 4.0 International License)

\section{PENDAHULUAN}

Kurikulum 2013 adalah sebuah kurikulum baru yang dibuat oleh pemerintah untuk memajukan pendidikan di Indonesia. Banyak wancana pro dan kontra dalam pelaksanaan kurikulum 2013. Dalam sebuah media ada yang menyatakan pelaksanaan kurikulum 2013 dianggap premature karena kesiapan sekolah dan guru yang masih minim. Tetapi tidak sedikit yang mendukung kurikulum 2013 cepat terlaksana. Menurut Syawal Gultom (2013:1), pengembangan kurikulum 2006 (KTSP) menjadi kurikulum 2013 dikarenakan pada kurikulum 2006 (KTSP) masih banyak kekurangan antara lain (1) konten kurikulum yang masih terlalu padat yang di tunjukkan dengan banyaknya matapelajaran dan banyak materi yang keluasan dan tingkat kesukarannya melampaui tingkat perkembangan usia anak; (2) Kurikulum belum sepenuhnya berbasis kompetensi sesuai dengan tuntutan fungsi dan tujuan pendidikan nasional; (3) beberapa kompetensi yang dibutuhkan sesuai dengan perkembangan kebutuhan (misalnya pendidikan karakter, metodologi pembelajaran aktif, keseimbangan soft skills dan hard skills, kewirausahaan) belum terakomodasi didalam kurikulum; (4) standar proses pembelajaran belum menggambarkan urutan pembelajaran yang rinci sehingga membuka peluang penafsiran yang beraneka ragam dan berujung pada pembelajaran yang berpusat pada guru. Gunawan, B. I. (2017) menambahkan bahwa Perbedaan KTSP dan Kurikulum 2013 adalah pada KTSP merumuskan tujuan bidang pengajaran yang dilihat dari skenario pembelajaran. Sedangkan penerapan Kurilum 2013 adalah pembelajaran terdiri dari 5 M (mengamati, menanya, mengumpulkan informasi, mengasosiasi, dan mengkomunikasikan). Pada Kurikulum KTSP lebih mengutamakan kognitif sedangkan pada Kurikulum 2013 lebih kepada aspek afektif, psikomotor baru kognitif. Kurikulum 2013 lebih mengedepankan aspek sikap, keterampilan dan baru pengetahuan (Machali, I.,2014).

Guru yang sesuai dengan kurikulum 2013 mengoptimalkan peran guru sebagai sumber belajar, kehadiran guru dalam pembelajaran sebagai perantara antara sumber belajar bagi siswa. Guru menyajikan pokok permasalahan pembelajaran kepada siswa dan siswa menerima, menelaah dan membahas materi itu sehingga menjadi miliknya (Pujiono, S., 2014). Guru sebagai fasilitator, guru harus dapat menjadi partner dan memfasilitasi rasa lapar belejar dari peserta didik, 
maka guru perlu mendalami dan memahami hal-hal yang berhubungan dengan berbagai media dan sumber belajar. Guru sebagai pengelola, guru harus dapat mengatur apa yang ada didalam kelas saat proses pembelajara, disamping itu kemampuan pengelolaan merupakan salah satu dari kompetensi pedagogik seorang guru, peran guru sebagai pengelola sangat vital karena akan berdampak pada lancar atau tidaknya proses pembelajaran serta hasil yang akan dicapai dari proses pembelajaran. Guru sebagai demonstrator, adalah peran untuk mempertunjukkan kepada siswa segala sesuatu yang dapat membuat siswa lebih mengerti dan memahami setiap pesan yang disampaikan, ada dua konteks guru sebagai demonstrator, yang pertama guru harus menunjukkan sikap-sikap yang terpuji, dalam konteks ini guru berperan sebagai model dan teladan bagi setiap siswa, yang kedua guru harus dapat menunjukkan bagaimana caranya agar setiap materi pelajaran dapat lebih dipahami dan dihayati oleh setiap siswa.

Guru sebagai pembimbing, membimbing siswa agar dapat menemukan berbagai potensi yang dimilikinya sebagai bekal hidup mereka, membimbing siswa agar dapat mencapai dan melaksanakan tugas-tugas perkembangan mereka, sehingga dengan ketercapaian itu ia dapat bertumbuh dan berkembang sebagai manusia ideal yang menjadi harapan setiap orang tua dan masyarakat. Guru sebagai motivator, proses pembelajaran akan berhasil manakala siswa mempunyai motivasi belajar siswa, untuk memperoleh hasil belaar yang optimal, guru dituntuk kreatif membangkitkan mootivasi belajar siwa, sehingga terbentuk prilaku belajar siswa yang efektif (Sadikin, A., 2015). Guru sebagai evaluator, guru berperan untuk mengumpulkam data atau informasi tentang keberhasilan pembelajaran yang telah dilakukan, terdapat dua fungsi dalam memerankan perannya sebagai evaluator (Fitria, Y., \& Harlis, H. ,2016).

Pertama, untuk menentukan keberhasilan siswa dalam mencapai tujuan yang telah ditentukan atau menentukan keberhasilan siswa dalam menyerap materi kurikulum. Kedua, untuk menentukan keberhasilan guru dalam melaksanakan seluruh kegiatan yang telah diprogramkan, sebagai kegiatan yang bertujuan untuk menilai keberhasilan siswa, evaluasi memegang peranan yang sangat penting. Sebab evaluasi guru dapat menentukan apakah siswa yang diajarnya sudah memiliki kompetensi yang telah di tetapkan, sehingga mereka layak diberikan program pembelajaran baru, atau malah sebaliknya siswa belum dapat mencapai standar minimal sehingga mereka perlu diberikan program remedial, evaluasi dilakukan bukan hanya untuk siswa akan tetapi dapat digunakan untuk menilai kinera guru itu sendiri, berdasarkan hasil evaluasi apakah guru telah melaksanakan proses pembelajaran sesuai dengan perencanaan atau belum apa sajakah yang perlu di perbaiki.

Sasaran utama kurikulum 2013 adalah guru, karena gurulah yang menerapkan kurikulum 2013 kepada siswanya (Agustina, M. R., Suraida, S., Alfian, A., \& Syefrinando, B., 2018). Dari penerapan kurikulum 2013 ini akan dilihat sejauh mana kesiapan guru Penjas terhadap pelaksanaan kurikulum 2013. Oleh sebab itu, guru harus memiliki kompetensi sesuai dengan kurikulum 2013. Mengingat banyak 
faktor yang belum tercapai dalam mendukung proses pelaksanaan kurikulum 2013, seperti sarana dan prasarana yang kurang memadai, kualitas guru yang akan menerapkan kurikulum 2013 dan juga media serta materi yang akan disampaikan (Sadikin, A., 2015).

Mata pelajaran pendidikan jasmani, olahraga dan kesehatan merupakan bagian dari pendidikan serta keseluruhan dalam proses pembelajarannya yang menggunakan aktifitas jasmani dan kebiasaan hidup sehat menuju pada pertumbuhan dengan pengembangan jasmani, mental, sosial dan emosional yang serasi, selaras dan seimbang. Penerapan kurikulum 2013 khususnya dibidang pendidikan jasmani dan olahraga aktifitas fisik sangat diutamakan yang pada dasarnya tidak jauh berbeda dengan KTSP. Aktifitas yang dilaksanakan disekolah merupakan salah satu wadah untuk membentuk kepribadian yang kuat, sportifitas, kedisplinan serta kreatifitas yang semuanya merupakan dasar pendidikan

Penerapan pelaksanaan kurikulum 2013 akan dilaksanakan pada tahun ajaran 2014/2015, sejak tahun 2013 pemerintah melalui Departemen Pendidikan Nasional telah melakukan sosialisasi kurikulum 2013. Atas prakarsa Depdiknas dan Diknas Sumut, sosialisasi kurikulum 2013 telah dilakukan dibeberapa sekolah dikota Medan. Berdasarkan data referensi Kementrian Pendidikan dan Budaya jumlah data satuan pendidikan (sekolah) di kota Medan untuk jenjang pendidikan Sekolah Menengah Pertama (SMP) dan Madrasah Tsanawiyah (MTs) adalah sebanyak 481 sekolah. Sedangkan untuk jenjang pendidikan SMP Negeri dan MTs Negeri di kota Medan berjumlah 48 sekolah.

Berdasarkan observasi yang dilakukan penulis, masih ada guru penjas yang belum menerapkan kurikulum 2013 kepada siswanya dikarenakan guru-guru penjas masih kesulitan menerapkan, banyak kekurangan atau minimnya sarana dan prasarana dan buku pedoman mengajar yang sangat sedikit dan terbatas, bahkan guna untuk mempersiapkan guru-guru dalam pelaksanaan kurikulum 2013 khususnya kurikulum 2013 penjas, olahraga dan kesehatan belum pernah mengikuti penataran/penyuluhan atau sosialisasi kurikulum 2013 penjas, olahraga dan kesehatan secara tersendiri dari pemerintah terkait. Berdasarkan latar belakang di atas, maka penulis pada kesempatan ini, akan melakukan penelitian yang berjudul: Survey Penerapan Kurikulum 2013 pada Mata Pelajaran Penjas di Sekolah Menengah Pertama Negeri Se-Kecamatan Medan Tembung.

Pendidikan jasmani pada hakekatnya adalah proses pendidikan yang memanfaatkan aktivitas fisik untuk menghasilkan perubahan dalam kualitas individu, baik dalam hal fisik, mental, serta emosional, pendidikan jasmani memperlakukan seseorang anak sebagai suatu kesatuan yang utuh, makhluk total, dari pada hanya menganggapnya sebagai seseorang yang terpisah kualitas fisik dan mentalnya Toto Subroto (2000:4) mendefenisikan Pendidikan jasmani merupakan proses pendidikan" artinya bahwa melalui prosesn pendidikan jasmani yang kondusif siswa dibantu untuk mewujudkan dirinya sesuai dengan tahap pertumbuhan dan perkembangan secara optimal, sehingga ia mencapai suatu taraf kedewasaan tertentu. 
Dalam proses pengajaran unsur belajar memegang peranan yang sangat penting. Ini berarti bahwa berhasil tidaknya proses pengajaran banyak bergantung pada bagaiman proses belajar yang dialami oleh siswa sebagai anak didik. Oleh karena itu, penting bagi setiap guru memahami sebaik-baiknya proses belajar siswa agar dapat memberikan bimbingan dan menyediakan lingkungan belajar yang tepat bagi siswa tersebut. Seperti yang dikemukakan oleh winkel dalam edward purba,dkk (2003:2).

Dalam proses balajar-mengajar akan di peroleh suatu hasil yang pada umumnya disebut hasil pengajaran atau prestasi. Oleh karena itu prinsip belajar tidak dapat dipisahkan dari apa yang terjadi dalam proses belajar mengajar itu sendiri. Untuk mengetahui sejauh mana hasil yang dicapai maka perlu diadakan penilaian, pengukuran dan evaluasi. Menurut sudjana (2009:3) " hasil berlajar siswa pada hakikatnya adalah perubahan tingkah laku sebagai hasil belajar dalam pengertian yang lebih luas mencakup bidang kognitif, afektif dan psikomotor."

Menurut rogen yang dikutip nurhasanah (2000:1) alat atau instrumen untuk mempertemukan kedua pihak agar anak dapat merealisasikan bakatnya secara optimal dan di samping itu juga belajar menyumbangkan jasanya untuk meningkatkan tara hidup dalam masyarakatnya. KTSP disusun dalam rangka memenuhi amanat yang tertuang dalam undang-undang Republik Indonesia Nomor 20 Tahun 2003 tentang sistem pendidikan nasional dan dan peraturan pemerintah Republik Indonesia Nomor 19 Tahun 2005 tentang standar nasional pendidikan. Dalam penyusunan nya, KTSP jenjang pendidikan dasar dan menengah mengacu pada peraturan Mentri Pendidikan Nasional Nomor 22 Tahun 2006 tentang standar isi untuk satuan pendidikan Dasar dan Menengah, Peraturan Menteri Pendidikan Nasional Nomor 23 Tahun 2006 tentang standar kompetensi.

Kurikulum 2013 merupakan upaya untuk menyempurnakan kurikulum agar lebih familiar dengan guru karena mereka banyak dilibatkan diharapkan banyak memiliki tanggung jawab yang memadai. Pelaksanaan proses pembelajaran adalah proses yang diatur sedemikian rupa menurut langkah-langkah tertentu agar pelaksanaan mencapai hasil yang diharapkan (Nana Sudjana, 2010; Arum, A. S., \& Saring Marsudi, M. P.,2017). Menurut (Syaiful Bahri dan Aswan Zain 2010:1) pelaksanaan pembelajaran adalah suatu kegiatan yang bernilai edukatif, nilai edukatif mewarnai interaksi yang terjadi antara guru dan siswa. Interaksi yang bernilai edukatif dikarenakan pelaksanaan pembelajaran yang dilakukan diarahkan untuk mencapai tujuan tertentu yang telah dirumuskan sebelum pelaksanaan pembelajaran dimulai. Belajar dan mengejar sebagai suatu proses sudah tentu harus dapat mengembangkan dan menjawab beberapa persoalan yang mendasar. Keempat persoalan (tujuan, bahan, metode, dan alat serta penilaian) menjadi komponen utama yang harus dipenuhi dalam prose belajar mengajar (Rebawa, J., 2015). 


\section{METODE PENELITIAN}

Penelitan ini dilaksanakan di SMP Negeri se- Kecamatan Medan tembung. Penelitian ini direncanakan akan dilaksakan pada semester ganjil tahun ajaran 2019/2020, mulai bulan september 2019, Waktu penelitian ini kurang lebih dilaksanakan 2 bulan. Populasi dalam penelitian ini adalah guru pendidikan jasmani olahraga dan kesehatan SMP Negeri di Kecamatan medan tembung yaitu SMP Negeri 27, SMP Negeri 17, SMP Negeri 29, SMP Negeri 35 dan MTSN 2 yang keseluruhan berjumlah 10 orang.

Sampel yang diambil dari penelitian ini menggunakan teknnik total sampling, dimana teknik penentuan sampel semua anggota populasi digunakan sebagai sampel dalam penelitian. Metode yang digunakan dalam penelitian ini adalah metode diskriptif kuantitatif. Dengan metode tersebut dapat diperoleh informasi yang aktual tentang bagaimana penerapan Kurikulum 2013 di SMP Negeri Se-Kecamatan medan Tembung. Instrumen yang digunakan untuk memperoleh data penelitian angket atau kuesioner tertutup yang akan divalidkan kepada guru-guru SMP Negeri di Kecamatan Medan Tembung, dan dalam angket ini, jawaban yang diajukan sudah disediakan. Responden diminta untuk memilih jawaban yang sesuai dengan dirinya.

\section{HASIL PENELITIAN DAN PEMBAHASAN}

Untuk indikator Perangkat SMP Negeri 27 di peroleh nilai yang terdapat pada aspek yang diamati, guru yang pertama mendapatkan skor $=61$, sementara untuk guru yang kedua mendapatkan skor $=59$. Sehingga jumlah keseluruhan data mentah 120 yang seharusnya 150. Hal ini diperoleh dari jumlah guru di SMP tersebut sebanyak 2 orang sehingga perhitungannya dilakukan dengan cara perolehan hasil dari ke dua guru tersebut. Untuk indikator Pelaksanaan SMP Negeri 27 di peroleh nilai untuk pengamatan pelaksanaan pembelajaran, untuk guru yang pertama mendapatkan skor $=94$ sementara untuk guru yang kedua mendapatkan skor $=77$ sehingga jumlah keseluruhan data mentah 171 yang seharusnya 240. Hal ni diperoleh dari jumlah guru di SMP tersebut sebanyak 2 orang sehingga perhitungannya dilakukan dengan cara perolehan hasil dari ke dua guru tersebut

Untuk indikator Penilaian SMP Negeri 27 di peroleh nilai untuk pengamatan penilaian, guru yang pertama mendapatkan skor $=24$ sementara untuk guru yang kedua mendapatkan skor $=24$, sehingga jumlah keseluruhan data mentah 48 yang seharusnya 60. Untuk indikator Perangkat SMP Negeri 35 di peroleh juga nilai yang terdapat pada aspek yang diamati guru yang pertama mendapatkan skor $=59$ sementara untuk guru yang ke dua mendapatkan skor $=61$, sehingga jumlah keseluruhan data mentah 120 yang seharusnya 150. Hal ini di peroleh dari jumlah guru di SMP tersebut sebanyak 2 orang sehingga perhitungannya dilakukan dengan cara perolehan hasil dari ke dua guru tersebut.

Untuk indikator Pelaksanaan SMP Negeri 35 di peroleh nilai untuk pengamatan pelaksanaan pembelajaran, untuk guru yang pertama mendapatkan skor $=95$ 
sementara untuk guru yang kedua mendapatkan skor $=87$, sehingga jumlah keseluruhan data mentah 182 yang seharusnya 240. Hal ni diperoleh dari jumlah guru di SMP tersebut sebanyak 2 orang sehingga perhitungannya dilakukan dengan cara perolehan hasil dari ke dua guru tersebut

Untuk indikator Penilaian SMP Negeri 35 di peroleh nilai untuk pengamatan penilaian, guru yang pertama mendapatkan skor $=24$ sementara untuk guru yang kedua mendapatkan skor $=24$, sehingga jumlah keseluruhan data mentah 48 yang seharusnya 60 . Hal ni diperoleh dari jumlah guru di SMP tersebut sebanyak 2 orang sehingga perhitungannya dilakukan dengan cara perolehan hasil dari ke dua guru tersebut. Untuk indikator Perangkat SMP Negeri 17 di peroleh juga nilai yang terdapat pada aspek yang diamati, guru yang pertama mendapatkan skor $=60$ sementara untuk guru yang kedua mendapatkan skor $=59$, sehingga jumlah keseluruhan data mentah 119 yang seharusnya 150. Hal ini di peroleh dari jumlah guru di SMP tersebut sebanyak 2 orang sehingga perhitungannya dilakukan dengan cara perolehan hasil dari ke dua guru tersebut.

Untuk indikator Pelaksanaan SMP Negeri 17 di peroleh nilai untuk pengamatan pelaksanaan pembelajaran, untuk guru yang pertama mendapatkan skor $=95$ sementara untuk untuk guru yang kedua mendapatkan skor $=78$, sehingga jumlah keseluruhan data mentah 173 yang seharusnya 240. Hal ni diperoleh dari jumlah guru di SMP tersebut sebanyak 2 orang sehingga perhitungannya dilakukan dengan cara perolehan hasil dari ke dua guru tersebut. Untuk indikator Penilaian SMP Negeri 17 di peroleh nilai untuk pengamatan peniliaian untuk guru yang pertama mendapatkan skor $=24$ sementara untuk guru yang kedaua mendapatkan skor $=24$, sehingga jumlah keseluruhan data mentah 48 seharusnya 60 . Hal ni diperoleh dari jumlah guru di SMP tersebut sebanyak 2 orang sehingga perhitungannya dilakukan dengan cara perolehan hasil dari ke dua guru tersebut.

Untuk indikator Perangkat SMP Negeri 29 di peroleh juga nilai yang terdapat pada aspek yang diamati, guru yang pertama mendapatkan skor $=61$ sementara untuk guru yang kedua mendapatkan skor $=61$, sehingga jumlah keseluruhan data mentah 122 yang seharusnya 150. Hal ini di peroleh dari jumlah guru di SMP tersebut sebanyak 2 orang sehingga perhitungannya dilakukan dengan cara perolehan hasil dari ke dua guru tersebut. Untuk indikator Pelaksanaan SMP Negeri 29 di peroleh nilai untuk pengamatan pelaksanaan pembelajaran, untuk guru yang pertama mendapatkan skor = 91 sementara untuk guru yang kedua mendapatakan skor $=93$, sehingga jumlah keseluruhan data mentah 184 yang seharusnya 240 . Hal ni diperoleh dari jumlah guru di SMP tersebut sebanyak 2 orang sehingga perhitungannya dilakukan dengan cara perolehan hasil dari ke dua guru tersebut.

Untuk indikator Penilaian SMP Negeri 29 di peroleh nilai untuk pengamatan penilaian, untuk guru yang pertama mendapatkan skor $=25$ sementara untuk guru yang kedua mendapatkan skor $=24$, sehingga jumlah keseluruhan data mentah 49 yang seharusnya 60 . Hal ni diperoleh dari jumlah guru di SMP tersebut sebanyak 2 orang sehingga perhitungannya dilakukan dengan cara perolehan hasil dari ke dua guru tersebut. Untuk indikator Perangkat MTSN 2 di peroleh juga nilai yang terdapat 
pada aspek yang diamati guru yang pertama mendapatkan skor $=60$ sementara untuk guru yang kedua mendapatkan skor $=59$, sehingga jumlah keseluruhan data mentah 119 yang seharusnya 150. Hal ini di peroleh dari jumlah guru di SMP tersebut sebanyak 2 orang sehingga perhitungannya dilakukan dengan cara perolehan hasil dari ke dua guru tersebut.

Untuk indikator Pelaksanaan MTSN di peroleh nilai untuk pengamatan pembelajaran , untuk guru yang pertama mendapatkan skor $=96$ sementara untuk guru yang kedua mendapatkan skor $=95$, sehingga jumlah keseluruhan data mentah 191 yang seharusnya 240. Hal ni diperoleh dari jumlah guru di SMP tersebut sebanyak 2 orang sehingga perhitungannya dilakukan dengan cara perolehan hasil dari ke dua guru tersebut. Untuk indikator Penilaian MTSN 2 di peroleh nilai untuk pengamatan penilaian, untuk guru yang pertama mendapatkan skor $=24$ sementara untuk guru yang kedua mendapatkan skor $=24$, sehingga jumlah keseluruhan data mentah 48 yang seharusnya 60 . Hal ni diperoleh dari jumlah guru di SMP tersebut sebanyak 2 orang sehingga perhitungannya dilakukan dengan cara perolehan hasil dari ke dua guru tersebut.

Setelah data dideskripsikan, untuk mengetahui survey penerapan kurikulum 2013 pada mata pelajaran penjas di SMP Negeri Se-kecamatan Medan Tembung, Hal ini berarti bahwa penerapan kurikulum 2013 di MTSN 2 dalam Kategori "Baik" yaitu pada interval $72 \%-81 \%$. Kemudian dapat kita simpulkan bahwa penerapan kurikulum 2013 pada mata pelajaran penjas di sekolah menengah pertama negeri se-kecamatan medan tembung berada di persentase $77,46 \%$, didapat dari total seluruh data mentah dan data seharusnya dari skor guru yang berada di 5 SMP Negeri yang ada di Kecamatan medan tembung berikut penjumlahannya :

$$
\begin{aligned}
\mathrm{P} & =\mathrm{F} / \mathrm{N} \cdot 100 \\
& =1743 / 2250 \cdot 100 \\
& =0,7746 \cdot 100 \\
& =77,46 \%
\end{aligned}
$$

Hal ini berarti bahwa Penerapan Kurikulum 2013 Pada Mata Pelajaran Penjas di Sekolah Menengah Pertama Negeri Se-kecamatan medan tembung dalam Kategori "Baik" yaitu pada $72 \%$ - 81\% . Dari data yang di peroleh diatas nampak bahwa Survey Penerapan Kurikulum 2013 pada mata pelajaran penjas sekecamatan medan tembung telah di uji kebenarannya. Mengenai proses penerapan kurikulum 2013 di masing-masing SMP Negeri se-kecamatan medan tembung.

Dari hasil perhitungan data diatas, maka dapat di nyatakan bahwa survey penerapan kurikulum 2013 pada mata pelajaran penjas di SMP Negeri Sekecamatan Medan Tembung untuk SMP Negeri 27 dalam kategori "Baik", dengan persentase rata-rata sebesar $75,33 \%$ dengan Kekurangan yang harus di perbaiki adalah pada pelaksanaan pembelajaran dimana guru belum malaksanakan $5 \mathrm{M}$ yang dimana adalah bagian didalam kurikulum 2013, setelah itu dalam pemanfaatan waktu yang kurang efesien dan juga dalam hal menguasai kelas, kemudian masih 
lemahnya dalam melakukan penilaian dan proses hasil belajar, hal ini berkenaan dengan penilaian akhir yang sesuai dengan kurikulum 2013.

Kemudian untuk SMP Negeri 35 juga dalam kategori "Baik" dengan presentase rata-rata sebesar $78,00 \%$. Dengan kekurangan yang harus di perbaiki adalah pada pelaksanaan pembalajaran masih ada guru yang belum melaksanakan 5M secara runtut, kemudian masih lemah nya dalam melakukan penilaian dan proses hasil belajar, hal ini berkenaan dengan kurikulum 2013 dan siswa kurang disiplin dalam melaksanakan pembelajaran, hal ini berkenaan dengan indikator menguasai kelas, sehingga data yang diperoleh belum dapat tergolong sempurna.

Setelah itu untuk SMP Negeri 17 juga dalam kategori "baik", dengan persentase rata-rata sebesar $75,55 \%$. Dengan kekurangan yang harus diperbaiki pada pelaksanaan pembelajaran dimana masih ada guru yg belum mempersiapkan siswa nya untuk belajar, kemudian masih lemahnya dalam melakukan 5M dalam proses pembelajaran yang dimana berkaitan dalam kuirkulum 2013 dan masih lemahnya melakukan penilaian akhir yang sesuai dengan kurikulum 2013, kemudian dari kategori perangkat yang masih belum lengkap yaitu data RPP dan alokasi waktu dan siswa kurang disiplin dalam melaksanakan pembelajaran dapat dilihat dari seragam (baju) yang digunakan ketika dalam kegiatan pembelajaran, hal ini berkenaan dengan indikator menguasi kelas sehingga data yang diperoleh belum dapat tergoglong sempuran

Dan di SMP Negeri 29 juga dalam kategori "baik" dengan persentase rata-rata $78,88 \%$ dengan kekurangan yang harus diperbaiki adalah pada pelakasanaan pemebelajaran dimana masih ada guru masih belum mempersiapkan siswa nya untuk belajar dan melakukan $5 \mathrm{M}$ dan melakukan refleksi di penutup pelajaran. Setelah itu di MTSN 2 juga dalam kategori "baik" dengan persentasu rata-rata $79,55 \%$. Dengan kekurangan yang harus di perbaiki pada pelaksanaan di pelakasanaan pembelajaran di kategori memanfaatkan alokasi waktu, kemudian di dalam penilaian yang sesuai dengan kurikulum 2013. Kebanyakan guru masih belum siap melaksanakan kurikulum 2013, hal ini dikarenakan pelatihan-pelatihan yang diikuti terlalu singkat. Terutama dalam bagian penilaian terhadap hasil belajar dan proses belajar (Ruja, I. N., 2017). Sedangakn menurut penelitian Wangid, M. N., Mustadi, A., Erviana, V. Y., \& Arifin, S. (2014) guru di D.I Yogyakarta siap melaksanakan kurikulum 2013. Laporan senada juga disampaikan oleh Pujiono, S. (2014) guru di D.I Yogyakarta telah siap melaksanakan Kurikulum 2013. Pranawati, N. (2014) melakukan penelitian di Mojokerto melaporkan pelaksanaan Kurikulum 2013 belum berjalan dengan baik. Ramdhan, P. S., Hendri, W., \& Har, E. (2015) melaporkan bahwa di Sumatera Barat guru juga mengalami kesulitan dalam penerapan kurikulum 2013. 


\section{KESIMPULAN}

Sebagai kesimpulan dari hasil penelitian tentang survey penerapan kurikulum 2103 pada mata pelajaran penjas di SMP Negeri Se-Kecamatan medan tembung adalah (1) SMP Negeri 27 Medan pada kategori "Baik" dengan persentase 75,33\%. (2) SMP Negeri 35 Medan pada kategori "Baik" dengan persentase $78 \%$. (3) SMP Negeri 17 Medan pada kategori "Baik" dengan persentase 75,55\%. (4) SMP Negeri 29 Medan pada kategori "Baik" dengan persentase 78,88\%. (5) MTSN 2 Medan pada kategori "Baik" dengan persentase 79,55\%. Dengan demikian hasil survey tentang penerapan kurikulum 2013 pada pembalajaran penjas di SMP Negeri Se-Kecamatan Medan Tembung dalam kategori "Baik" dengan hasil nilai persentase rata-ratanya sebesar $77,46 \%$.

\section{DAFTAR PUSTAKA}

Agustina, M. R., Suraida, S., Alfian, A., \& Syefrinando, B. (2018). Authentic Assessment Analysis Based on the Curriculum 2013 at SMP Negeri 7 Muaro Jambi. BIODIK, 4(2), 135-144.

Alawiyah Faridah. 2013. Peran Guru Dalam Kurikulum 2103. Jurnal Aspirasi Volume 4 No. 1 Juni 2013

Anwar, Ruliansyah,. 2014. Hal-hal Yang Mendasari Penerapan Kurikulum 2013. Jurnal Humaniora Volume 5 No. 1 April 2014.

Arikunto (2010). Manajemen Penelitian. Jakarta: Rineka Cipta.

Arum, A. S., \& Saring Marsudi, M. P. (2017). Persepsi Guru Tentang Pembelajaran pada Kurikulum 2013 dan Kurikulum Tingkat Satuan Pendidikan di SD Muhammadiyah 24 Gajahan Surakarta(Doctoral dissertation, Universitas Muhammadiyah Surakarta).

E.Mulyasa (2013). Pengembangan dan Implementasi Kurikulum 2013. Bandung : Remaja Rosdakarya.

Fitria, Y., \& Harlis, H. (2016). PENGARUH PENERAPAN MODEL PEMBELAJARAN INKUIRI TERBIMBING TERHADAP KETERAMPILAN PROSES SAINS SISWA PADA PEMBELAJARAN BIOLOGI KELAS VIII SMP NEGERI 11 KOTA JAMBI. BIODIK, 2(2), 67-72.

Gunawan, B. I. (2017). Perbandingan implementasi kurikulum tingkat satuan pendidikan (KTSP) dan kurikulum 2013 di SMAN 1 Sinjai Utara. Jurnal Mirai Management, 1(1), 1-9.

Gultom Syawal (2013). Pedoman Pelatihan Implementasi Kurikulum 2013. Jakarta: Kementrian Pendidikan dan Kebudayaan referensi.data .kemendikbud.go.id.

Jupriadi. 2017. Analisis dan Implementasi Penerapan Kurikulum 2013 Terhadap Gaya Mengajar Guru di Sekolah. Faktor Jurnal IImiah Kependidikan Volume 4 No.3 Nopember 2017.

Machali, I. (2014). Kebijakan perubahan kurikulum 2013 dalam menyongsong Indonesia emas tahun 2045. Jurnal Pendidikan Islam, 3(1), 71-94. https://doi.org/10.14421/jpi.2014.31.71-94

Mardiana, Safitri, dkk. 2017. Implementasi Kurikulum 2013 dalam pembelajaran di SMA Negeri 1 Metro. Jurnal Historia Volume 5 Nomor 1, Tahun 2017. 
Pranawati, N. (2014). Survei Keterlaksanaan Kurikulum 2013 Pada Mata Pelajaran Penjasorkes Di SMP Sasaran Kota Mojokerto. Jurnal Pendidikan Olahraga dan Kesehatan, 2(3).

Pujiono, S. (2014). Kesiapan Guru Bahasa Indonesia SMP dalam Implementasi Kurikulum 2013. LITERA, 13(2).

Purba Edward (2014). Filsafat Pendidikan. Medan: UNIMED Press.

Ramdhan, P. S., Hendri, W., \& Har, E. (2015). ANALISIS KESULITAN GURU BIOLOGI DALAM PELAKSANAAN PEMBELAJARAN BILOGI SMA NEGERI DI KOTA PADANG. Abstract of Undergraduate, Faculty of Education, Bung Hatta University, 4(5).

Rebawa, J. (2015). Studi komparasi implementasi kurikulum KTSP dengan kurikulum 2013 mapel Pendidikan Agama Islam pada kajian standar kompetensi Tahun Pelajaran 2013/2014 (Doctoral dissertation, IAIN Salatiga).

Ruja, I. N. (2017). Survey Permasalahan Implementasi Kurikulum Nasional 2013 Mata Pelajaran IImu Pengetahuan Sosial Sekolah Menengah Pertama Di Jawa Timur. Sejarah Dan Budaya: Jurnal Sejarah, Budaya, Dan Pengajarannya, 9(2), 193-199.

Sadikin, A. (2015). Hubungan EQ (Emotional Quotient) dengan hasil belajar mahasiswa biologi semester Ganjil Tahun Ajaran 2014/2015. BIODIK, 1(1).

Wangid, M. N., Mustadi, A., Erviana, V. Y., \& Arifin, S. (2014). Kesiapan guru SD dalam pelaksanaan pembelajaran tematik-integratif pada kurikulum 2013 di DIY. Jurnal Prima Edukasia, 2(2), 175-182. 